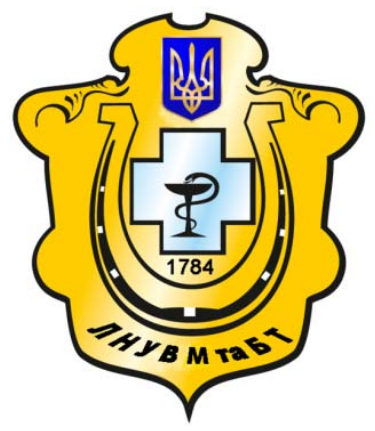

Науковий вісник Львівського національного університету ветеринарної медицини та біотехнологій імені С.3. Гжицького

Scientific Messenger of Lviv National University of Veterinary Medicine and Biotechnologies named after S.Z. Gzhytskyj

doi:10.15421/nvlvet6629

ISSN 2413-5550 print

ISSN 2518-1327 online

$\underline{\text { http://nvlvet.com.ua/ }}$

UDC 619:616.2:616.07:636.1

\title{
Additional diagnostic procedures for equine respiratory diseases
}

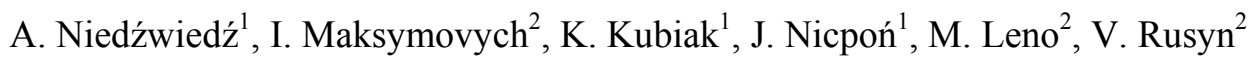 \\ maksym_vet@ukr.net \\ ${ }^{1}$ Department of Internal Diseases with Clinic for Horses, Dogs and Cats, \\ Faculty of Veterinary Medicine, Wrocław University of Environmental and Life Sciences, Wrockaw, Poland \\ ${ }^{2}$ Department of internal diseases and clinical diagnostics, Faculty of Veterinary Medicine, \\ Lviv National University of Veterinary Medicine and Biotechnologies named after Gzhytskyj, \\ Pekarska Str., 50, Lviv, 79010, Ukraine
}

\begin{abstract}
Respiratory diseases in horses are common, and with the increase in the population of this species, they pose a serious challenge to practicing veterinarians. In the case of respiratory diseases, a primary factor in determining the correct diagnosis is the skillful combination of data collected from the patient history, a detailed clinical examination and the results of additional tests. Auscultation of the lungs in horses is performed routinely, if respiratory diseases are suspected, but still an underestimated source of information is the percussion of the chest. With the development of diagnostic techniques applicable in human medicine, new opportunities have also emerged to examine the respiratory tract in horses. Increasingly, standard diagnostics performed in these animals include endoscopy, radiology, ultrasound, blood gas testing and collecting material to microbial culture. Some diseases can be diagnosed only during endoscopy while the animal is moving. For this purpose, a treadmill with a variable speed is used. Currently, bronchoalveolar lavage (BAL), tracheal wash $(T W)$ and centesis of the thorax are applied more often. An examination of high diagnostic value is lung scintigraphy, but due to the price of the equipment and isotope storage problems it is not available in most developing countries. These tests are aimed at both a correct diagnosis and monitoring the course of treatment.
\end{abstract}

Key words: horses, respiratory diseases, airway endoscopy, bronchoalveolar lavage, tracheal wash.

\section{Застосування додаткових методів дослідження для діагностики респіра- торних захворювань коней}

\author{
А. Нєдзвєдзь ${ }^{1}$, І. Максимович ${ }^{2}$, К. Куб'як ${ }^{1}, \breve{̆}_{\text {. Ніцпонь }}{ }^{1}$, М. Леньо ${ }^{2}$, В. Русин ${ }^{2}$ \\ maksym_vet@ukr.net
}

\footnotetext{
${ }^{l}$ Кафедра внутрішніх хвороб з клінікою коней, собак і котів Факультет ветеринарної медичини, Врочлавський природничий університет, Врочлав, Польща

${ }^{2}$ Кафедра внутрішніх хвороб тварин та клінічної діагностики, Факультет ветеринарної медицини Львівський національний університет ветеринарної медицини та біотехнологій імені С.3. Гжицького, вул. Пекарська, 50, м. Львів, 79010, Украӥна
}

Захворювання органів дихання у коней широко розповсюджені, щчо пов'язано зі збільшенням популяції иього виду тварин. Хвороби органів дихання являють собою серйозну проблему для практикуючих лікарів ветеринарної медицини. У випадку появи захворювань дихальних шляхів, головним фактором при постановиі правильного діагнозу є вміле поєднання даних, зібраних з історії хвороби тварини, повне клінічне дослідження і результати застосування додаткових методів.

При підозрінні на захворювання органів дихання проводиться аускультація легень, проте на сьогодні недооиінюється інформативна иінність перкусії грудної клітки в коней.

3 розвитком методів візуальної діагностики, щу застосовуються в гуманній медицині, вони стали також широко впроваджуватися у ветеринарну медицину, зокрема і для дослідження дихальних иляхів у коней. Все частіше базові досліджен-

Citation:

Niedźwiedź, A., Maksymovych, I., Kubiak, K., Nicpoń, J., Leno, M., Rusyn, V. (2016). Additional diagnostic procedures for equine respiratory diseases. Scientific Messenger LNUVMBT named after S.Z. Gzhytskyj, 18, 2(66), 140-143. 
ня у иъього виду тварин включають ендоскопічне, рентгенологічне та ультразвукове дослідження, визначення кислотноосновного балансу крові, мікробіологічне дослідження. Окремі захворювання можуть діагностуватися тільки за допомогою ендоскопї під час руху тварини. 3 ичєю метою використовується бігова доріжка зі змінною швидкістю.

В даний час з діагносчтичною метою все частіше застосовується бронхоальвеолярний лаваж (БАЛ), аспірація трахеї (tracheal wash, TW) і центез грудної клітки. Високоінформативним методом дослідження є сиинтиграфія легень, однак через високу вартість обладнання і зберігання ізотопів цей метод недоступний в більшості ветеринарних клінік.

Застосування візуальних методів дослідження коней спрямовані на постановку правильного діагнозу та контролю за ефективністю лікування.

Ключові слова: коні, респіраторні хвороби, візуальна діагностика, бронхоальвеолярний лаваж, аспірація трахеї.

Endoscopic examination of the respiratory tract. Examination of the respiratory tract with an endoscope is irreplaceable and it is often impossible to make a correct diagnosis without it. It enables direct visual contact with the upper respiratory tract, trachea and bronchi. As with any test, endoscopy of the respiratory system should never be evaluated independently of the clinical symptoms and the results of other tests. Unfortunately, very often in practice we deal with the selective execution of high-tech procedures, while ignoring these basic, equally valuable diagnostic methods (Smith et al., 1994).

The test is performed using endoscopic sets consisting of a video-endoscope, video channel, a light source, a video processor and an LCD monitor. The whole set should be placed on a special apparatus trolley. However, due to the large size of the whole device and the ability to move it only on a hard and level surface, such a solution can only be afforded mainly by a veterinary clinic. Equipment manufactured by leading brands such as Karl Storz $^{\circledR}$, Canon ${ }^{\circledR}$ and Nikon ${ }^{\circledR}$ provides optimal parameters for the user and high quality and reliability. The most commonly used endoscopes have an outer diameter of 9,5-13,0 mm, which allows one to perform testing both in foals as well as in adult horses, whereas the standard length should not be less than 1,8-2,0 m. Of special importance is the option to save digital data on the computer's hard drive or print images.

The examination needs the assistance of at least two people, one of whom holds the horse with a twitch applied to the animal's upper lip, and the other directs and supports the working part of the endoscope. The medical examiner then has both hands free, which allows easy handling of the endoscope head and interpretation of images. Quite controversial is the use of sedatives before examination of the upper respiratory tract, because they can impair the function of the throat and larynx, which in turn can alter the result. Instead, a combination of xylazine or detomidine with butorphanol can be successfully used which, in the case of inflammation of the trachea and further respiratory tract, effectively eliminates the cough reflex and reduces patient discomfort during the examination (Sweene et al., 1992).

The working part of the endoscope is introduced into the lower nasal meatus, directing it slightly downward and medially. This step should be carried out fairly quickly, because it is a part of the examination, during which animals may react quite violently. It is recommended that a detailed inspection of the front part of the nasal meatuses is not performed when the endoscope enters the nasal cavity, but when it is removed. At the end of the examination the animal is quieter and this allows for a careful examination of this part of the respiratory system.
When the endoscope has entered about $35 \mathrm{~cm}$ into the nasal cavity in an adult horse, its throat and larynx should be available for inspection. The presence of hyperplastic lymphoid follicles is normal in this area. They may be present in varying amounts. The follicles are most common in young horses, and the amount is reduced with aging. On inspecting the throat, the palatopharyngeal arch, soft palate as well as guttural pouches can be assessed. The guttural pouches are available for inspection using a thin endoscope; however, biopsy forceps need to be introduced into the working channel. This allows the removal of cartilage caps which close the entrance into the guttural pouch (Figure 1,2) and the introduction of endoscope tip there (Sweene et al., 1992; Savage, 1997).

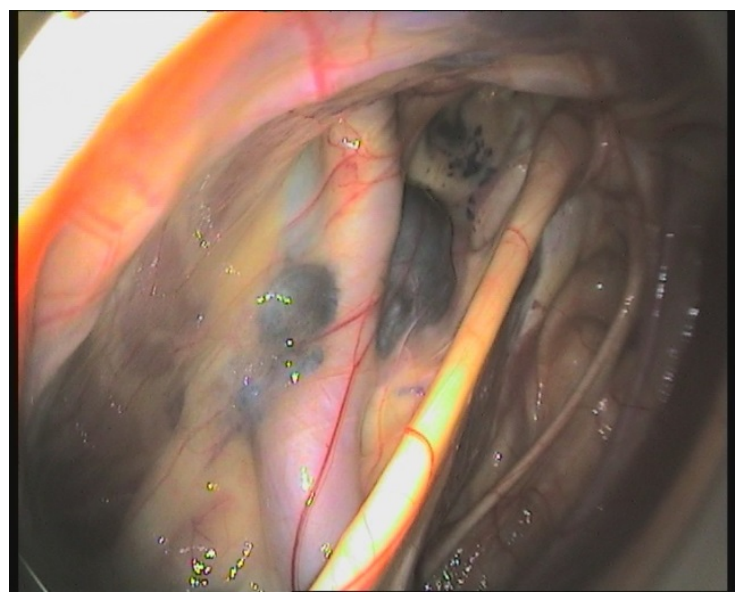

Figure 1. Guttural pouch melanoma

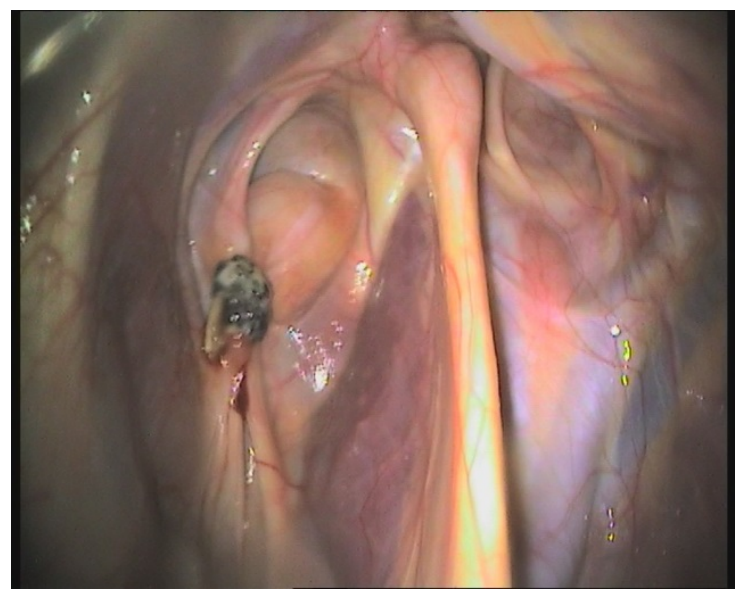

Figure 2. Guttural pouch mycosis

During the examination of this area, attention should be paid to the appearance of mucosa, pulmonary vascularity, and the presence of any lesions and erosions. The location of the epiglottis should be dorsal to the palate, 
and its edge "serrated" with visible vascularity on its dorsal surface. Testing for laryngeal hemiplegia involves the assessment of arytenoid cartilage symmetry and their abduction. However, one should be aware of the possibility of the misinterpretation of images viewed due to image distortion as a result of the endoscope being positioned asymmetrically. If there is any doubt about the diagnosis, the test should be repeated by introducing an endoscope through the other nostril or, if necessary, performed in motion, on a treadmill.

The next stage of examination is to introduce the endoscope into the trachea. Tracheoscopy is quite often done in order to determine exercise-induced bleeding in horses. When the endoscope has entered into the trachea, attention is drawn to any secretions. A large amount of residual mucus is characteristic for recurrent airway obstruction (RAO) and inflammatory airway disease (IAD). While inspecting the trachea, and after administration of a small amount of physiological fluid by working channel, bronchial secretions can be collected to perform cytology (Hoffman et al., 1998). Due to the possibility of contamination of the sample during its extraction by the working channel, tracheal secretions should be collected with a disposable, sterile cannula for microbiological examination. A difficulty in collecting biological material can occur when secretions are dense or a small diameter cannula is used. Then, the only option is to collect the tracheal aspirates via the transdermal route. A strong cough may hinder the tracheal bifurcation and main bronchi inspection (Figure 3 ). This is due to stimulation of the numerous receptors there. In such a situation, it is desirable to administer a small amount of lidocaine or mepivacaine via the working channel (Darien et al., 1990).

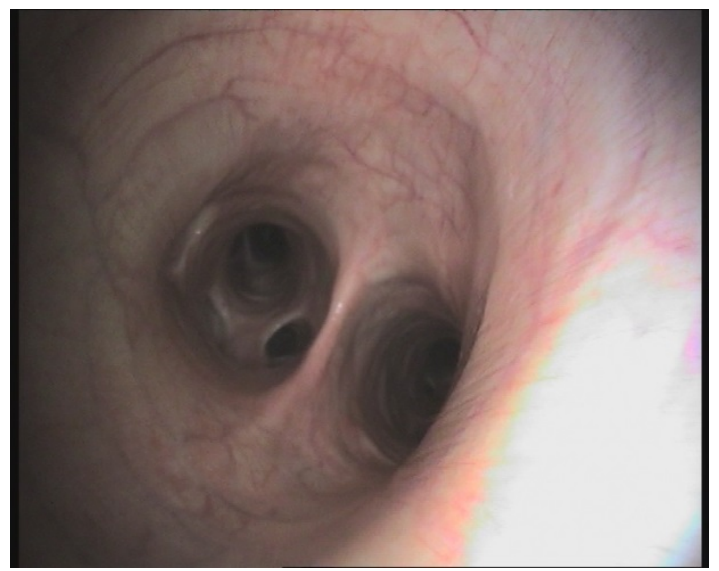

Figure 3. Tracheal bifurcation and main bronchi inspection

One of the procedures performed during bronchoscopy is transbronchial lung biopsy, which is indicated mainly in endobronchial lesions. Another important diagnostic procedure is bronchoalveolar lavage (BAL). This represents a liquid biopsy of further parts of the bronchial tree and alveoli. Collected cells are useful for the diagnosis of non-infectious diseases, neoplasia and interstitial lung diseases. BAL is actually the only examination confirming recurrent airway obstruction (RAO). The diagnostic value of this test is extremely significant, and the risk of complications low.
Bronchoscopy cannot be performed in patients that do not cooperate or which, in spite of sedation, are restless. It should not be performed in patients with cardiovascular instability, a low cardiac output, arrhythmias or significant anemia (Davidson and Martin, 2003).

Complications after the procedure are fairly rare. Many of them develop as a result of the use of sedatives or anesthetics, and in older horses with chronic obstructive diseases.

Tracheal aspirates. Samples of secretions from the tracheal wall can be used for cytologic evaluation, bacteriologic culture and virus testing. Depending on the indications, tracheal mucus samples can be collected through the endoscope working channel, or transdermally. The other method allows one to go round the upper airways, which eliminates the risk of sample contamination by saprophytic bacterial flora, which reside in the nose, throat, and larynx (Couëtil et al., 2007).

The puncture is performed on a standing animal, after administration of sedatives. Before performing the procedure, the puncture site, a $10 \times 10 \mathrm{~cm}$ area located right in the middle of the lower half of the neck, should be clipped and disinfected and local infiltration anesthesia should be employed to the skin and subcutaneous tissue with $2 \%$ lignocaine. The puncture can be easier through an incision of the skin and subcutaneous tissue using a scalpel blade.

The puncture is performed between two adjacent cricoid cartilages. Most frequently used for this purpose is a simple injection needle, sized 12 or $14 \mathrm{G}$ or $8-10 \mathrm{G}$ trocar. Through the injected needle or trocar, a sterile polyethylene catheter is inserted into the interior of the trachea, by setting its tip in the direction of the bifurcatio trachaea.

A strong cough is normal, then, caused by irritation of receptors on the inner wall of the trachea. The air during coughing should not move the catheter tip in the direction of the upper part of the trachea and larynx, as this may distort the results. The next step is to remove the injection needle or trocar, which reduces the probability of damage to the catheter and contamination of the sample. Using the catheter, approximately $25-35 \mathrm{ml}$ of slightly warmed, sterile $0,9 \% \mathrm{NaCl}$ solution is introduced, and immediately after, fluid can be aspired. If it is necessary, the procedure can be repeated 3-4 times to increase the volume of the sample (Derksen et al., 1989; Bain, 1997).

The most common complications of collecting tracheal aspirates are injection site abscesses, inflammation of the skin and connective tissue, and, rarely, subcutaneous emphysema, or damage to the cricoid cartilages.

Thoracentesis. Thoracentesis is a procedure to collect fluid from the pleural cavity and its cytological or bacteriological assessment to determine the etiology of the fluid in the pleural cavity. The most common diseases with an accumulation of fluid in the pleural cavity are pneumonia and pleural chest wound penetrating into the pleural cavity, neoplasia and various cysts. The presence of fluid in the pleural cavity can be suspected based on auscultation and percussion of the chest. The presence of fluid is confirmed by ultrasound examination of the chest, and a simple puncture can be performed for diagnostic or therapeutic purposes (Shott and Mansmann, 1990). 
The chest puncture technique is relatively simple. Thoracentesis is performed between the 6th and 7th intercostal spaces, 3-4 cm above the cartilage-bone connection (Figure 4). Prior to surgery, the injection site should be prepared by carefully shaving, washing and disinfecting an area measuring $5 \times 5 \mathrm{~cm}$, whose central point corresponds to the puncture site. Thus prepared, the operating field should be anesthetized using a sterile anesthetic agent. The puncture is performed with a thick puncture needle or a device comprising a needle and a catheter which must be connected to a threeway stopcock. It is connected with a 30 or $50 \mathrm{ml}$ syringe and a conduit to discharge the syringe. There are also readymade, disposable sets of needles, syringes, stopcocks and catheters designed for easy, safe puncturing of the pleural cavity. The needle should be inserted perpendicularly to the skin, along the front edge of the rib, which allows the vein, artery and nerve located on the back to be avoided. To prevent damage to the lungs, it is recommended not to aspire fluid from the pleural cavity under a high vacuum (Light, 1990).

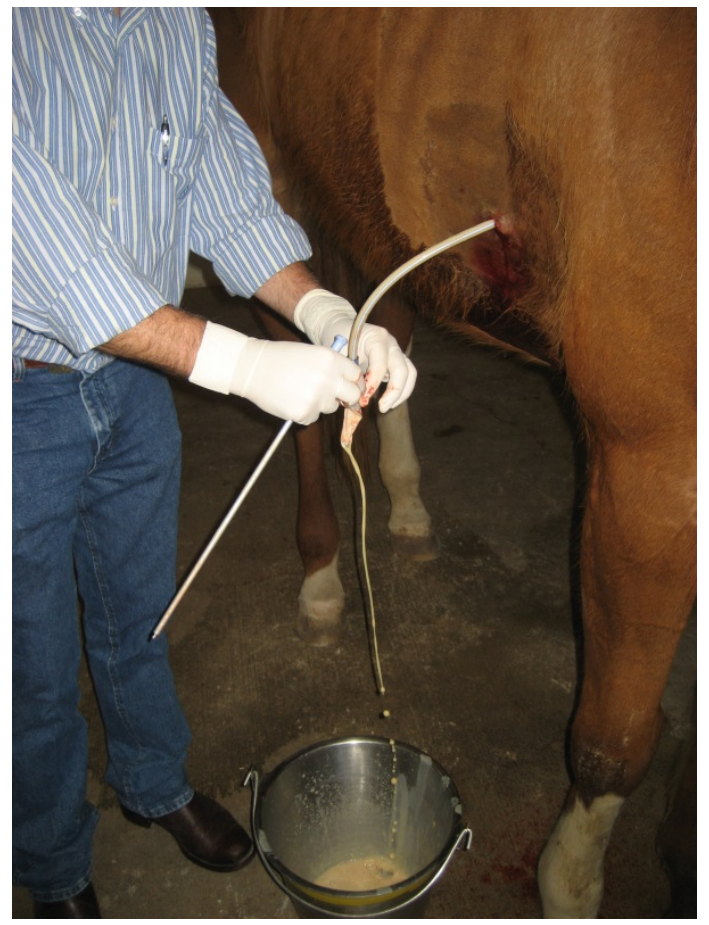

Figure 4. Performance of thoracentesis in horse

In the case of an unsuccessful puncture in a given place, it is recommended to repeat the procedure at another point on the chest. This is due to the possibility of the leakage of fluid from the pleural cavity and the formation of soft tissue local dermatitis and cellulitis.

Fluid is collected into tubes with EDTA for cytological assessment and to test tubes for biochemical analysis. For microbiological analysis, two tubes are used, one of which must be filled entirely; therefore, air is removed and anaerobic bacteria can be cultured.

The most important contra-indications to pleural cavity puncture are coagulation disorders, respiratory failure (except in cases when the puncture's goal is to treat it), and cardiac arrhythmias. Each time, before insertion of the needle into the pleural cavity local infection of the chest wall should be ruled out.
The most common complications caused by puncturing the pleural cavity are a mild pneumothorax and inflammation of the skin and connective tissue around the injection site. Other less common but more serious complications are mainly puncture of the heart, lungs and diaphragm laceration and puncture of the spleen or liver (Rush and Mair, 2004).

\section{Conclusions}

Multiple diagnostic tools are available for evaluating upper and lower respiratory tract of horses. Detailed history, clinical examination together with additional tests, including airway endoscopy, TW and BAL are critical to determining the correct diagnoses. During selection of additional tests, one should consider patient temperament, clinical status and financial possibilities of the owner. Understanding how to deal with the sample, collection procedures and further handling of the sample, is critical to achieving an accurate diagnosis.

\section{References}

Smith, B.L., Aguilera-Torejro, E., Tyler, W.S. (1994). Endoscopic anatomy and map of the equine bronchial tree. Equine Vet. J. 26, 283-290.

Sweene, C.R., Weiher, J., Baez, J.L. (1992) Bronchoscopy of the horse. J. Vet. Res. 53, 1953-1956.

Savage, C.J. (1997). Evaluation of the equine respiratory system using physical examination and endoscopy. Vet. Clin. North Am. Equine Pract. 3, 443-462.

Hoffman, A.M., Mazan, M.R., Ellenerg, S. (1998). Association between bronchoalveolar lavage cytologic features and airway reactivity in horses with history of exercise intolerance. Amer. J. Vet. Res. 59, 176-181.

Darien, B.J., Brown, C.M., Walker, R.D. (1990). A tracheoscopic technique for obtaining uncontaminated lower airway secretions for bacterial culture in the horse. Equine Vet. J. 22, 170-173.

Davidson, E.J., Martin, B.B. (2003). Diagnosis of upper respiratory tract diseases in the performance horse. Vet. Clin. North Am. Equine Pract. 1, 51-62.

Couëtil, L.L., Hoffman, A.M., Hodgson, J. et all. (2007). Inflammatory Airway Disease of Horses. J. Vet. Intern. Med. 21, 356-361.

Bain, F.T. (1997). Cytology of the respiratory tract. Vet. Clin. North Am. Equine Pract. 3, 477-486.

Derksen, F., Brown, C., Sonea, B. (1989). Comparison of transtracheal aspirate and bronchoalveolar lavage cytology in 50 horses. Equine Vet. J. 21, 23-26.

Shott, H.C., Mansmann, R.A. (1990). Thoracic drainage in horses. Comp. Cont. Edu. Pract. Vet. 12, 251-261.

Light, R.E. (1990). Parapneumonic effusions and infections of the pleural space. In: Pleural Disease. Philadelphia: Lea \& Febiger, 129-149.

Rush, B., Mair, T. (2004). Equine Respiratory Diseases. Blackwell Publishing

Стаття надійшла до редакції 17.09.2016 